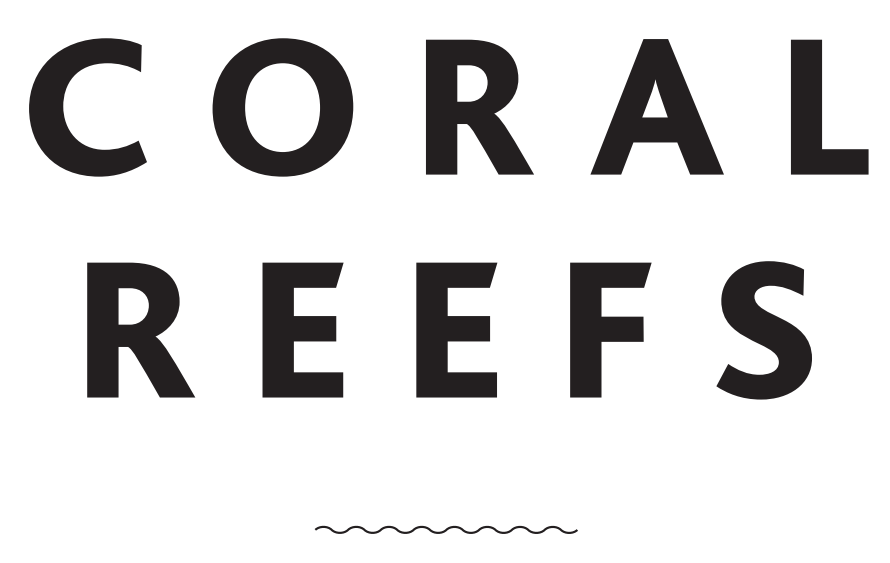

A NATURAL HISTORY 


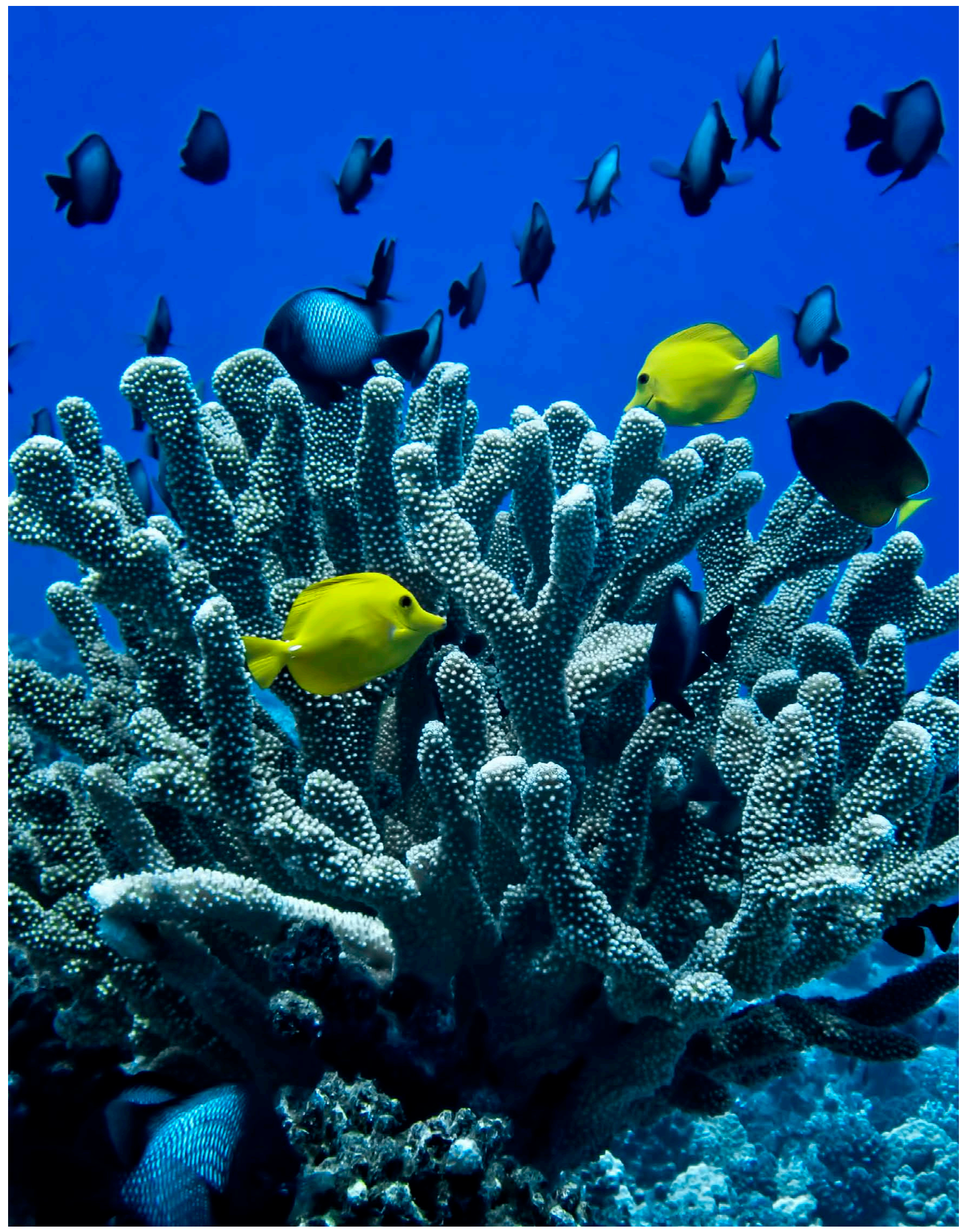




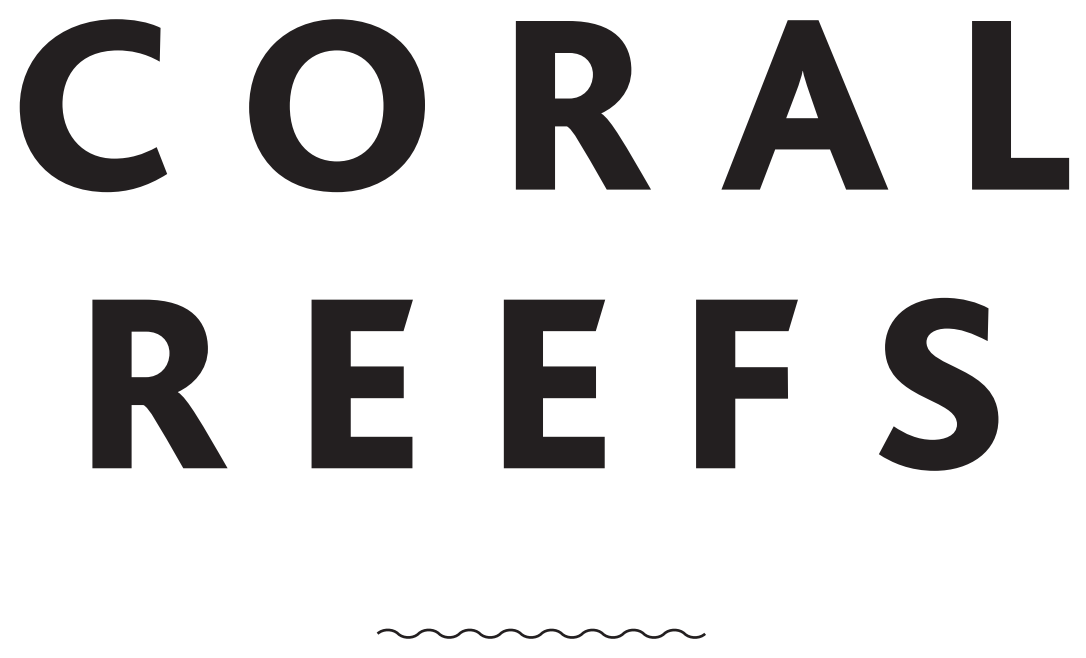

\section{A NATURAL HISTORY}

Charles Sheppard

Consultant Editor

Russell Kelley 